Arab Univ. J. Agric. Sci., Ain Shams Univ., Cairo, Egypt

28(3), 885-891, 2020

Website: http://ajs.journals.ekb.eg

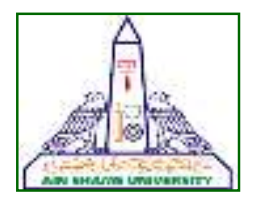

\title{
OPTIMIZATION OF ALOCASIA AMAZONICA PROLIFERATION THROUGH IN-VITRO CULTURE TECHNIQUE
}

$[64]$

Reda M. Abdel-Baset ${ }^{{ }^{*}}$, Mohamed S.E. ${ }^{2}$, Saadawy F.M. ${ }^{1}$ and Hewidy M. ${ }^{2}$

1. Ornamental Plant Researches Dept., Hort. Research Institute, Agric. Research Center Giza, Egypt

2. Hortic. Dept., Fac. of Agric., Ain Shams Univ. P.O. Box 68, Hadayek Shoubra 11241, Cairo, Egypt

*Corresponding author: zahretelorchid@gmail.com

Received 8 August, 2020

Accepted 21 September, 2020

\section{ABSTRACT}

Excised explants were in-vitro cultured on multiplication medium of Murashige and Skoog (MS). This study was carried away inside the tissue culture lab. Horticulture Research Institute, Agricultural Research Center. Giza, Egypt through the period from 2015 to 2017 , to research some factors affecting in-vitro propagation of the indoor ornamental plant Alocasia amazonica using benzyladenine amino purine (BAP) and Kinetin at 0, 1, 2, 3, 4 ppm and their interaction. The obtained results indicated that BAP gave the greatest number of shoots, plus the lowest values for shoot length, shoot fresh weight, number regarding roots and total chlorophyll content. Meanwhile, kinetin achieved the highest values for shoot length, shoot fresh weight although it was not necessarily significant. The same was observed in number of leaves, number of roots and total chlorophyll content with no significant difference. MS medium free of hormones demonstrated the greatest number of leaves, number of roots and total chlorophyll content, and the lowest values of number of shoots and shoot length. Using cytokinn at $1 \mathrm{ppm}$ gave the highest shoot length and number of leaves; and the second position for number of shoot and roots. As for 2 ppm of cytokinin application, it gave the greatest values of shoot length, number of leaves and shoot fresh weight, despite the last one was not significant. this concentration got also the other position for number of shoots, 3 ppm had the greatest number of shoots, and the lowest shoot length, number of roots and shoot fresh weight and $4 \mathrm{ppm}$ occupied the second grade concerning number of shoots, and the lowest grades for shoot length, shoot fresh weight, number of leaves, number of roots and total chlorophyll. Regarding the interaction between cytokinin type and concentration found that, the control treatment (Free MS) gave the highest number of leaves. Using BAP at 2 or $3 \mathrm{ppm}$ attained the highest number of shoots. Using Kin at 1 or 2 ppm attained the highest shoots length. Also, Using Kin at 2 ppm attained the highest fresh weight. The application of Kin at $1 \mathrm{ppm}$ was connected with the highest value of number of leaves. The development of roots showed great values on free medium of BAP and Kin as well as medium supplemented with Kin at 1 and $2 \mathrm{ppm}$. Whereas, root did not demonstrate any presence at higher concentrations of BAP of 2, 3 and $4 \mathrm{ppm}$. It is usually recommended to use the MS medium supplemented with BAP at $3 \mathrm{ppm}$ which often gave the highest number of shoots. However, the highest values for shoot length, shoot fresh weight and number of roots were recorded on particularly on MS medium supplemented with Kin at 2 ppm.

Keywords: Alocasia, BAP, Kin, multiplication.

\section{INTRODUCTION}

Over 100 species were found of Alocasia known to technology and all are normally found in the region of Southeast Asian countries and neighboring island countries of the Pacific Sea. Alocasia x amazonica is a new hybrid and not a new species. It was developed in 1950's of the particular last century from Asiatic parents Alocasia sanderiana (Schott)G. Don) $x$ Alocasia longiloba(Miq. ). This is a hybrid fellow member of the family Araceae. This plant has in 
no way existed within the rain woodland of the Amazon or perhaps South America. It provides never been observed normally in any virgin woodland in the world. InterNet Site 1 (2020).

Alocasia species are very well-known ornamental plants among plant collectors and landscape gardeners due to their foliar charm, patterns of leaf variegation and texture, along with tolerance to limited sunlight. Alocasia species are conventionally propagated through seeds and corms. However, conventional metheds of propagation are time consuming in addition to restrict the mass propagation of Alocasia species. (Jo et al 2008).

In-vitro culture methods of propagation are the alternatives method to meet the growing demand of both the domestic and the international markets. Despite the increasing commercial demand for Alocasia plants, only one tissue culture report is available for Alocasia macrorrhizos (Adelberg and Toler 2004), and there are few reports of in vitro propagation of $A$. amazonica and other species (Jo et al $2008 \& 2009$ and Bhatt et al 2013).

Hence it is necessary to be able to develop efficient and economically viable micro-propagation protocols in order to ensure conservation and meet the commercial demand for Alocasia species. Regarding the use of various cytokinins at different level represent an important value for proliferation of in vitro propagated plants.

Arab et al (2014) mentioned that the longest span of new microshoots associated with the GxN15 (hybrid of almond xpeach) rootstock was obtained within hormone-free MS medium. generally there is a significant connection between hormone level and even plantlet, in order that an rise in BAP level lead significantly in height lower. The existence of high amounts involving BAP in culture moderate triggered influence on shoot development.

Thus the target of this study was to find the proper cytokinin and concentration on proliferation of Alocasia amazonica.

\section{MATERIALS AND METHODS}

This kind of study was carried out inside the Tissue culture Lab, Horticulture Research Institute, Gardening Research Center, Giza, Egypt throughout the period from 2015 to 2017, to research the effect of cytokinin type and levels on in-vitro shoot growth of Alocasis amazonica. Inside vitro excised shoot explants of Alocaia amazonica have been obtained from the tissues culture facility in Zohryia
Garden. A factorial test was carried out making use of BAP and Kin as the first factor, from concentration of $0,1,2,3$ and $4 \mathrm{ppm}$ as the second factor. The explants were inoculated onto MS medium. 1 bud explant was inoculated into each glass container.

Every treatment was replicated 3 times, with 6 containers in each replicate. These kinds of treatments were completely randomized. Jars of this research were kept in typically the incubation room at $26 \pm 2^{\circ} \mathrm{C}$, under florescent lighting of 2000-2500 lux from 1618 day Inight varying for 8 weeks. Info of number of sets, shoot length, shoot fresh weight, number of root base and total chlorophyll content according to Saric et al (1976) were recorded. Information were statistically analyzed making use of analysis of variance while described by Snedecor and Cochran (1989) and means had been separated according to Duncan multiple comparison test with a probability level of $5 \%$ (Duncan, 1955) by SAS 95 computer program

\section{RESULTS}

\section{Number of shoots}

Cytokinin concentration, and type and their interaction showed significant effect on number of shoots (Table 1). The effect of cytokinin concentration on number of shoots was significant. The highest number (8.33 shoots) was obtained when cytokinin were applied at $3 \mathrm{ppm}$. The lowest one (4.33 shoots) was a result of using no cytokinins at all. The effect of cytokinin type was significant. Applying BAP gave an increase in the number of shoots when compared to Kin (8.67 and 3.93 shoots, respectively).

Table 1. Effect of cytokinin type, concentration and their interaction on number of shoots.

\begin{tabular}{|c|c|c|c|}
\hline \multirow{2}{*}{$\begin{array}{c}\text { Conc. } \\
\text { (ppm) }\end{array}$} & \multicolumn{2}{|c|}{ Cytokinin type } & \\
\hline 0 & BAP & KIN & Mean \\
\hline 1 & $4.33 \mathrm{~cd}$ & $4.33 \mathrm{~cd}$ & $4.33 \mathrm{~B}$ \\
2 & $9.33 \mathrm{~b}-\mathrm{d}$ & $4.00 \mathrm{~cd}$ & $5.67 \mathrm{AB}$ \\
3 & $13.00 \mathrm{a}-\mathrm{c}$ & $5.00 \mathrm{a}-\mathrm{d}$ & $7.00 \mathrm{AB}$ \\
4 & $9.67 \mathrm{ab}$ & $2.67 \mathrm{~d}$ & $8.33 \mathrm{~A}$ \\
\hline Mean & $8.67 \mathrm{~A}$ & $3.93 \mathrm{~B}$ & \\
\hline
\end{tabular}

Means with the same letter are not significantly different 
As for the interaction, it affected number of shoots significantly. The highest record in this concern resulted when BAP was used at 3 ppm (13.00 shoots). However, using BAP at 2 and 4 ppm shared also in the highest rank (9.00 and 9.67 shoots, respectively). The lowest numbers were a result of using kinetin at 3 and 4 ppm (3.67 and 2.67 shoots, respectively).

\section{Shoot length $(\mathrm{cm})$}

The concentration and type of cytokinin and their interaction showed significant effect on shoot length (Table 2). As for the concentration, applying cytokinins at 1 or $2 \mathrm{ppm}$ resulted in higher shoots length ( 6.33 and $6.00 \mathrm{~cm}$, respectively) compared to concentrations of 0,3 or 4 ppm $(3.45,3.10$ and 2.58 $\mathrm{cm}$, respectively).

Table 2. Effect of cytokinin type, concentration and their interaction on shoot length $(\mathrm{cm})$.

\begin{tabular}{|c|c|c|c|}
\hline $\begin{array}{c}\text { Conc. } \\
\text { (ppm) }\end{array}$ & $\begin{array}{c}\text { Cytokinin } \\
\text { BAP }\end{array}$ & $\begin{array}{c}\text { Type } \\
\text { KIN }\end{array}$ & Mean \\
\hline 0 & $3.45 \mathrm{bc}$ & $3.45 \mathrm{bc}$ & $3.45 \mathrm{~B}$ \\
1 & $3.17 \mathrm{bc}$ & $9.50 \mathrm{a}$ & $6.33 \mathrm{~A}$ \\
2 & $2.50 \mathrm{bc}$ & $9.50 \mathrm{a}$ & $6.00 \mathrm{~A}$ \\
3 & $2.13 \mathrm{c}$ & $4.07 \mathrm{~b}$ & $3.10 \mathrm{~B}$ \\
4 & $2.00 \mathrm{c}$ & $3.17 \mathrm{bc}$ & $2.58 \mathrm{~B}$ \\
\hline Mean & $2.65 \mathrm{~B}$ & $5.94 \mathrm{~A}$ & \\
\hline
\end{tabular}

Means with the same letter are not significantly different

Cytokinin type revealed significant effect on shoot length. The use of Kin gave higher shoot length than those induced by BAP (5.94 and 2.65 $\mathrm{cm}$, respectively).

Regarding the effect of interaction, using Kin at 1 or $2 \mathrm{ppm}$ gave the highest shoots length $(9.50 \mathrm{~cm}$ for both combinations). The lowest shoot lengths were obtained when explants were treated by BAP at 3 or 4 ppm (2.13 and $2.00 \mathrm{~cm}$, respectively).

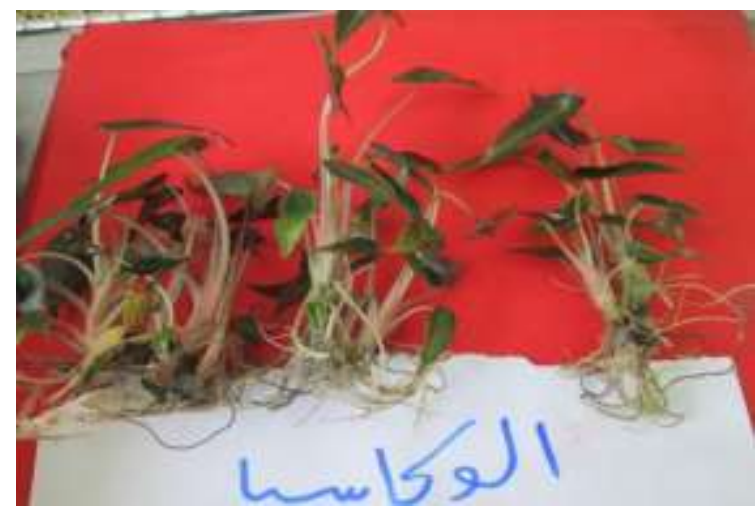

Fig. 1. Effect of cytokinin concentration on number of shoots kinetin $1 \mathrm{ml} / \mathrm{L}$

\section{Shoot fresh weight (g/culture)}

Effect of cytokinin concentration, type and their interaction on shoot fresh weight are presented in Table 3. The effect of cytokinin concentration did not show significant impact on shoot fresh weight. However, it could be detected that applying cytokinins at $2 \mathrm{ppm}$ produced the heaviest fresh shoots (9.87 g/cluster), while cytokinins at $4 \mathrm{ppm}$ induced the lightest ones $(4.40 \mathrm{~g} / \mathrm{cluster})$.

Regarding the effect of cytokinin type did not gave significant effect on shoot fresh weight. Despite this finding, it was noticed that using Kin produced heavier fresh shoots when compared to BAP (6.71 and $6.41 \mathrm{~g} /$ cluster, respectively).

As for the interaction, Kin application gave significant increase in fresh shoots weight at $2 \mathrm{ppm}$ (11.56 g/cluster). Applying Kin at 3 or 4 ppm gave the lightest fresh shoots $(3.43 \mathrm{~g} /$ cluster for both combinations).

Table 3. Effect of cytokinin type, concentration and their interaction on shoot fresh weight ( $\mathrm{g} / \mathrm{cluster}$ )

\begin{tabular}{|c|c|c|c|}
\hline $\begin{array}{c}\text { Conc. } \\
\text { (ppm) }\end{array}$ & Cytokinin & type & \multirow{2}{*}{ Mean } \\
\cline { 2 - 3 } & BAP & KIN & \\
\hline 0 & $5.48 \mathrm{ab}$ & $5.48 \mathrm{ab}$ & $5.48 \mathrm{~A}$ \\
1 & $5.91 \mathrm{ab}$ & $9.66 \mathrm{ab}$ & $7.79 \mathrm{~A}$ \\
2 & $8.17 \mathrm{ab}$ & $11.56 \mathrm{a}$ & $9.87 \mathrm{~A}$ \\
3 & $7.09 \mathrm{ab}$ & $3.43 \mathrm{~b}$ & $5.26 \mathrm{~A}$ \\
4 & $5.37 \mathrm{ab}$ & $3.43 \mathrm{~b}$ & $4.40 \mathrm{~A}$ \\
\hline Mean & $6.41 \mathrm{~A}^{\prime}$ & $6.71 \mathrm{~A}^{\prime}$ & \\
\hline
\end{tabular}

Means with the same letter are not significantly different 


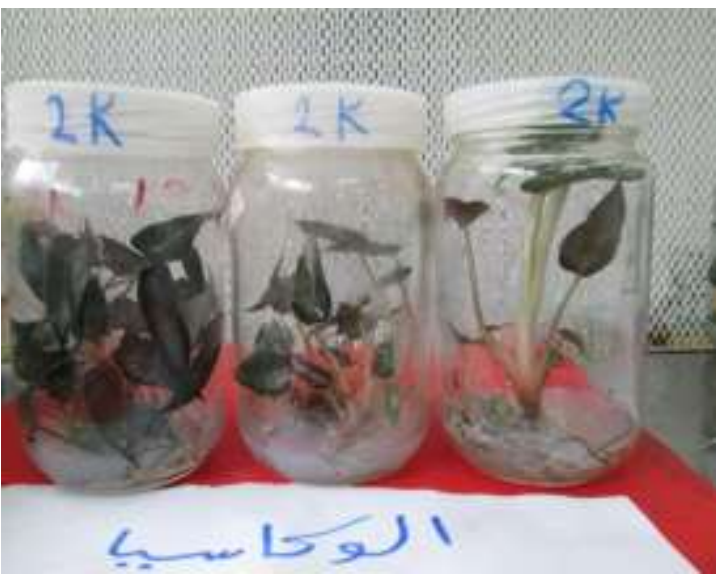

Fig. 2. Effect of cytokinin concentration on shoot fresh weight (Kinetin $2 \mathrm{ml} / \mathrm{l}$ )

\section{Number of leaves}

Effect of cytokinin concentration, type and their interaction on number of leaves are presented in Table 4.

The effect of cytokinin concentration revealed significant effect on number of leaves. The control treatment or cytokinins at $1 \mathrm{ppm}$ gave higher number of leaves (17.83 and 17.17 leaves, respectively). On the other hand, the highest concentration of cytokinins at 4 ppm resulted in the lowest number of leaves (6.17 leaves).

Table 4. Effect of cytokinin type, concentration and their interaction on number of leaves

\begin{tabular}{|c|c|c|c|}
\hline \multirow{2}{*}{$\begin{array}{c}\text { Conc. } \\
\text { (ppm) }\end{array}$} & \multicolumn{2}{|c|}{ Cytokinin type } & \multirow{2}{*}{ Mean } \\
\cline { 2 - 3 } & BAP & KIN & \\
\hline $\mathbf{0}$ & $17.83 \mathrm{a}$ & $17.83 \mathrm{a}$ & $17.83 \mathrm{~A}$ \\
$\mathbf{1}$ & $14.00 \mathrm{ab}$ & $20.33 \mathrm{a}$ & $17.17 \mathrm{~A}$ \\
$\mathbf{2}$ & $12.33 \mathrm{a}-\mathrm{c}$ & $14.83 \mathrm{ab}$ & $13.58 \mathrm{AB}$ \\
$\mathbf{3}$ & $7.33 \mathrm{bc}$ & $9.33 \mathrm{bc}$ & $8.33 \mathrm{BC}$ \\
$\mathbf{4}$ & $5.00 \mathrm{c}$ & $7.33 \mathrm{bc}$ & $6.17 \mathrm{C}$ \\
\hline Mean & $11.30 \mathrm{~A}$ & $13.93 \mathrm{~A}^{\prime}$ & \\
\hline
\end{tabular}

Means with the same letter are not significantly different

The effect of cytokinin type did not show significant effect on number of leaves. However, it could be noticed that using Kin induced more leaves when compared with BAP (13.93 and 11.30 leaves, respectively).

Concerning the interaction, it showed significant effect on number of leaves. The greatest number of leaves was obtained when explants were treated with Kin was at 1 ppm followed by non-supplemented medium with cytokinin (20.33 and 17.83 leaves, respectively). Treatments of BAP at 1 or 2 ppm, and Kin at 2 ppm shared also in the highest position (14.00, 12.33 and 14.83 leaves, respectively). Whereas the lowest number of leaves were developed when BAP was used at $4 \mathrm{ppm}$ (5.00 leaves).

\section{Number of roots}

Effect of cytokinin concentration, type and their interaction on number of roots is demonstrated in Table 5. Cytokinin concentration affected number of roots significantly. The greatest number of root was obtained when no cytokinins were used at all (14.67 roots). Values obtained at $1 \mathrm{ppm}$ concentration occupied the second position (10.58 roots), while applying cytokinins at 3 or $4 \mathrm{ppm}$ resulted in the lowest records (6.33 and 3.83 roots, respectively).

The effect of cytokinin type was significant. The use of Kin significantly increase number of roots when compared to BAP (12.57 and 4.40 roots, respectively).

Concerning for the interaction between cytokinin concentration and type, it showed significant effect on number of roots. The highest number of roots resulted when no cytokinins were applied at all (14.67 roots), followed by Kin at 1, 2 and 3 ppm (13.83, 14.00 and 12.67 roots, respectively). Whereas no roots were observed when BAP was used at 2, 3 or 4 ppm.

Table 5. Effect of cytokinin type, concentration and their interaction on number of roots

\begin{tabular}{|c|c|c|c|}
\hline \multirow{2}{*}{$\begin{array}{c}\text { Conc. } \\
\text { (ppm) }\end{array}$} & \multicolumn{2}{|c|}{ Cytokinin type } & \multirow{2}{*}{ Mean } \\
\cline { 2 - 3 } & BAP & KIN & \\
\hline $\mathbf{0}$ & $14.67 \mathrm{a}$ & $14.67 \mathrm{a}$ & $14.67 \mathrm{~A}$ \\
$\mathbf{1}$ & $7.33 \mathrm{c}$ & $13.83 \mathrm{a}$ & $10.58 \mathrm{~B}$ \\
$\mathbf{2}$ & $0.00 \mathrm{~d}$ & $14.00 \mathrm{a}$ & $7.00 \mathrm{BC}$ \\
$\mathbf{3}$ & $0.00 \mathrm{~d}$ & $12.67 \mathrm{ab}$ & $6.33 \mathrm{C}$ \\
$\mathbf{4}$ & $0.00 \mathrm{~d}$ & $7.67 \mathrm{bc}$ & $3.83 \mathrm{C}$ \\
\hline Mean & $4.40 \mathrm{~B}$ & $12.57 \mathrm{~A}^{\prime}$ & \\
\hline
\end{tabular}

Means with the same letter are not significantly different

\section{Total chlorophyll}

Effect of cytokinin concentration, type and their interaction on total chlorophyll content are presented in Table 6. The highest total chlorophyll content resulted when MS medium was free of cytokinins (7.86 mg/g F.W.), while the lowest value resulted when cytokinin level was 4 ppm (3.25 mg/g F.W.). 
Regarding the effect of cytokinins type, the use of Kin gave higher content of total chlorophyll when compared to application of BAP (6.59 and 3.99 $\mathrm{mg} / \mathrm{g}$ F.W., respectively).

As for the interaction, the addition of Kin at 1 ppm produced the highest total chlorophyll content (8.07 $\mathrm{mg} / \mathrm{g}$ F.W.), while BAP at $4 \mathrm{ppm}$ induced the lowest content (1.85 mg/g F.W.)

Table 6. Effect of cytokinin type, concentration and their interaction on total chlorophyll content $(\mathrm{mg} / \mathrm{g}$ F.W.)

\begin{tabular}{|c|c|c|c|}
\hline $\begin{array}{c}\text { Conc. } \\
\text { (ppm) }\end{array}$ & $\begin{array}{c}\text { Cytokinin } \\
\text { BAP }\end{array}$ & $\begin{array}{c}\text { type } \\
\text { KIN }\end{array}$ & Mean \\
\hline 0 & 7.86 & 7.86 & 7.86 \\
1 & 5.60 & 8.07 & 6.84 \\
2 & 2.59 & 6.27 & 4.43 \\
3 & 2.06 & 6.08 & 4.07 \\
4 & 1.85 & 4.65 & 3.25 \\
\hline Mean & 3.99 & 6.59 & \\
\hline
\end{tabular}

\section{DISCUSSION}

The findings are in compliance using what a whole lot of authors have noted. of these coincidences Thao et al (2003) mentioned that MS medium supplemented with $5 \mathrm{mg} / \mathrm{L}\{B A\}$ gave the best take regeneration of the. xamazonica in addition to A. cuculata.

Muhammad et al (2006) investigated the typically the effect of BAP in addition to kinetin up to 8. $0 \mathrm{mg} / \mathrm{L}$, on take proliferation of banana comprehensive resume. Basrai. they found of which the most of shoots/explant was achieved on MS medium containing 4. zero $\mathrm{mg} / \mathrm{L}$ BAP. Ružić and Vujović (2008) observed that will the highest shoot range and length of shoot obtained on media with 0. 5-1. $0 \mathrm{ppm}$ BA. on the particular contrary, poor multiplication seemed to be achieved on media using kinetin.

Maritano et al (2010) in comparison the effect of BA at 0-1 ppm about Evolvulus glomeratus and E. arizonicus (convolvulaceae). They discovered that this hightest number in addition to shoot length of Evolvulus glomeratus and E. arizonicus (convolvulaceae) were obtained with $1 \mathrm{ppm}$ BA. Radmann et al (2011) said that when different BAP concentrations were tested about 'Flordaguard' Prunus rootstocks, typically the maximum shoot number for every explant was obtained making use of with 4.0 $\mathrm{mg} / \mathrm{L}$ BAP. Ismail et al (2012) low concentration associated with BAP $(0.1-0.5 \mathrm{mg} / \mathrm{L})$ were sufficient with regard to shoot induction from crucial segments of Acacia auriculiformis. Bhatt et al (2013) declared that MS moderate supplemented with 2. zero $\mathrm{mg} / \mathrm{L}$ BA was maximum for the shoot growth of 5 Alocasia varieties. Ling et al (2013) found that kinetin with 1 $\mathrm{mg} / \mathrm{L}$ was far better than kinetin at 3-7 $\mathrm{mg} / \mathrm{L}$ in inducing typically the greatest number of shoots of $L a$ bisia pumila var. alata, (Fam. Primulaceae).

Arab et al (2014) stated the best shoot number associated with the GxN15 (cross of almond $\mathrm{x}$ peach)rootstock was found in MS medium supplemented with $1 \mathrm{mg} / \mathrm{L}$ BAP. Ashraf et al. (2014)cultured young take buds of Chlorophytum borivilianum on MS medium that contains BAP at $(0$, 2, 4, $6 \mathrm{ppm})$ in addition to kinetin( $0,2,3.8,5.7$ ppm). They will declared that BAP with 2-6 ppm was considerably effective on shoot propagatiation, while kin at 2-2. 7 ppm was considerably effective on shoot elongation, compared to the management. Karatas et al (2014) observed that maximum take regeneration frequency from explant of Ceratophlum demersum has been obtained at $0.05 \mathrm{mg} / \mathrm{L} \mathrm{BA}$. Tolera et al (2014) observed that will MS media fortified using 2 and $3 \mathrm{mg} / \mathrm{L}$ BAP were found to have the best number of shoot per explant, shoot size and number of foliage per shoot of sugarcane variety N14 and B41-227, respectively.

Ferdous et al (2015) pointed out that maximum number of shoots along with the longest shoots associated with banana cultivars Amirtasagar and Sabri were induced simply by $0.5 \mathrm{mg} / \mathrm{L} \mathrm{BAP}$. Sujin et al (2016) used different concentration (0-6 mg/L) of BAP and kinetin for multiplication of shoots of banana (Musas sp.) cv. Chenthuluvan. They found that typically the highest number and span of shoots were noticed in $3 \mathrm{mg} / \mathrm{L}$ involving BAP, compared to kinetin exact same concentration.

\section{REFERNCES}

Adelberg J. and Toler J. (2004). Comparison of agar and thin-film liquid systems for micropropagation of ornamental Alocasia and Colocasia. HortScience, 39, 1088-1092.

Arab M.M., Yadollahi A., Shojaeiyan A., S. Shokri and Ghojah S.M. (2014). Effects of nutrient media, different cytokinin types and their concentrations on in vitro multiplication of G x N15 (hybrid of almond $x$ peach) vegetative rootstock. J. Genetic Engin. Biotech., 12, 81-87.

Ashraf M.F., Aziz M.A., Kemat N. and Ismail I. 2014. Effect of cytokinin types, concentrations and their interactions on in vitro shoot regeneration of Chlorophytum borivilianum Sant. \& Fernandez. Electronic J. Biotech., 17, 275-279. 
Bhatt A., Stanly C. and Keng C.L. (2013). In vitro propagation of five Alocasia species. Horticultura Brasileira 31, 210-215.

Duncan D.B. (1955). Multiple range and multiple F tests, Biometrics, 11, 1-42.

Ferdous M.H., Masum Billah A.A., Mehraj H., Taufique T. and Jamal Uddin A.F.M. (2015). BAP and IBA pulsing for in vitro multiplication of banana cultivars through shoot-tip culture. J. Biosci. Agric. Res. 3, 87-95.

InterNet Site 1, (2020). https://www.exoticrainforest. com/Alocasia \%20 micholitziana\% 20\% 20 pc.html

Ismail H., Abdul Shukor N., Yusoff A.M., Hassan N.H., Zainudin F., Abdullah N. and Abdul Rahman S.S. (2012). In vitro shoot induction of Acacia auriculiformis from juvenile and mature sources. E3 J. Biotech. and Pharma. Res., 3, 88-93.

Jo, E.A., Tewari R.K., Hahn E.J. and Paek K.Y. (2009). In vitro sucrose concentration affects growth and acclimatization of Alocasia amazonica plantlets. Plant Cell Tiss. Organ. Cult., 96, 307-315.

Jo, U.A., Murthy H.N., Hahn E.J. and Paek K.Y. (2008). Micropropagation of Alocasia amazonica using semisolid and liquid cultures. In Vitro Cellular \& Developmental Biology-Plant, 44, 26-32.

Karatas, M., Aasim M. and Dogan M. (2014). Multiple Shoot Regeneration of Ceratophyllum demersum L. on Agar Solidified and Liquid Mediums. Fresenius Environ. Bull., 23, 1-9.

Ling A.P.K., Tan K.P. and Hussein S. (2013). Comparative effects of plant growth regulators on leaf and stem explants of Labisia pumila var. alata. J. Zhejiang Univ. Sci. B. (Biomed. \& Biotechnol.), 14, 621-631.

Maritano P.F., Alderete L.M., Torre M.C.P. and Escandón A.S. (2010). In vitro propagation and genetic stability analysis of Evolvulus spp. Biotechnological tools for the exploration of native germplasm with ornamental potential. In Vitro Cellular \& Develop. Biol.. Plant, 46, 64-70.

Muhammad A., Rashid H., Hussain I. and Naqvi S.M.S. (2006). Comparison of BAP and Kinetin on Proliferation Rate of Banana (Musa Spp.) Cv. Basrai. Conference: XVII Acorbat Intl. Meeting, Santa Catarina, Brasil, 17, 494-498.

Radmann E.B., Bianchi V.J., Fachinello J.C., L.V. Ferreira and de Oliveira R.P. (2011). In Vitro Multiplication of 'Flordaguard' Rootstock: Cytokinin Source and Concentration Effects, Explants Orientation and Period of Permanence in the Culture Medium. Braz. Arch. Biol. Technol., 54, 25-34.

Ružić D.V. and Vujović T.I. (2008). The effects of cytokinin types and their concentration on in vitro multiplication of sweet cherry cv. Lapins (Prunus avium L.). Hort. Sci. (Prague), 35, 1221.

Saric M., Kostrori R., Cupina T. and Geric I. (1967). "Chlorophyll Determination," Univ. Noven Sadu Prakitikum is kiziologize Bilijaka Beogard, Haucana, Anjiga.

Snedecor C.W. and Cochran W.G. (1989). Twoway classification, analysis of variance Statistical Methods ( $8^{\text {th }}$ Ed.). lowa State Univ. Press Ames, lowa, U.S.A. pp. 254-268.

Sujin D., Lohidas J. and Joselin J. (2016). Effect of BAP and NAA on in vitro multiplication of banana (Musa sp.) cv. Chenthuluvan. Life Science Archives, 2, 519-524.

Thao N.T.P., Mlyajima I., Ureshino K., Ozaki Y. and Okubo H. (2003). Micropropagation of Ornamental Alocasia. J. Fac. Agric., Kyushu Univ., 47, 277-282.

Tolera B., Diro M. and Belew D. (2014). In vitro Aseptic Culture Establishment of Sugarcane (Saccharum officinarum L.) Varieties Using Shoot Tip Explants. Advances in Crop Sci. and Tech., 2, 1-6. 
مجلة اتحاد الجامعات العربية للعلوم الزراعية، جامعة عين شمس، القاهرة، مصر مجلد(28)، عدد(3)، 885-895، 2020

Website: http://ajs.journals.ekb.eg

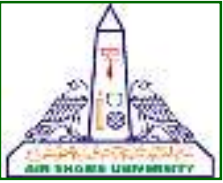

تحسين إكثار نبات الألوكاسيا معملياً

[64]

$$
\begin{aligned}
& \text { رضا محمد عبدالباسط1"- سهير السيد محمد حسن2-- محمد هويدي محمود رمضان2- } \\
& \text { فيصل محمد عبدالعليم سعداوي } 1 \\
& \text { 1- قسم بحوث الزينة وتنسيق الحدائق - معهد بحوث البساتين- مركز البحوث الزراعية- جيزة - مصر }
\end{aligned}
$$

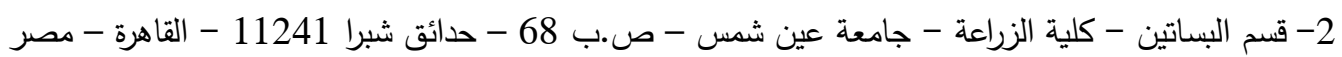

*Corresponding author: zahretelorchid@gmail.com

للأفرع و4 جزء فى المليون: جاء فى المركز الثانى لصفة الصنة

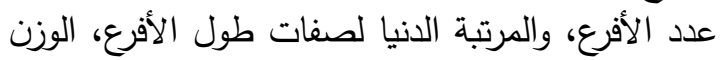

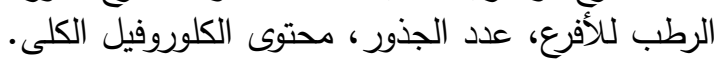

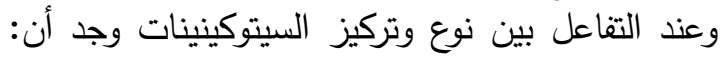

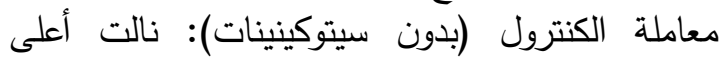

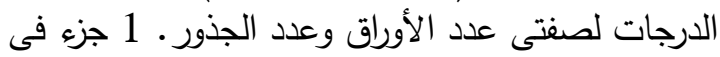

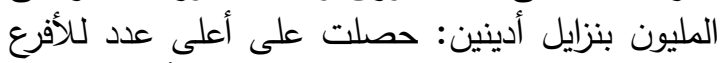

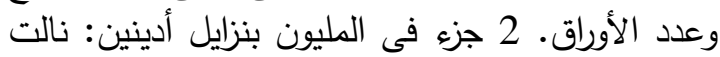

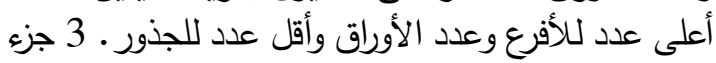

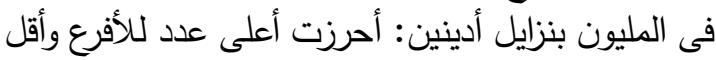

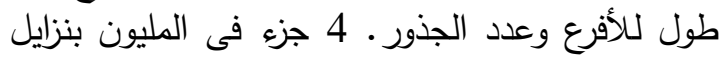

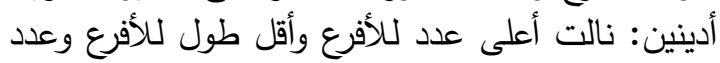

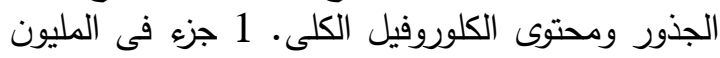

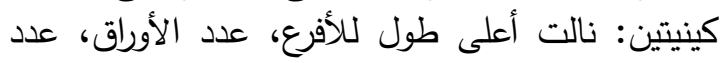

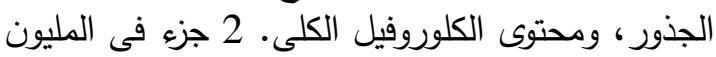

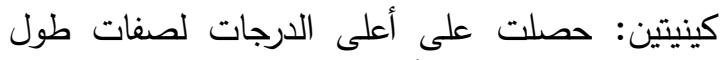

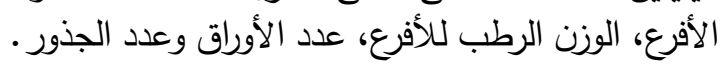

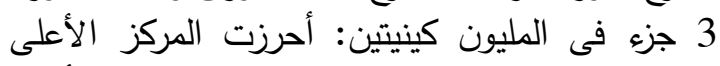

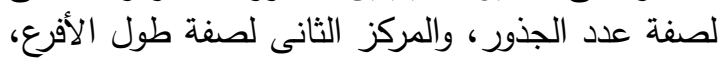

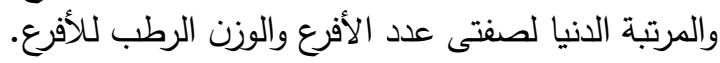

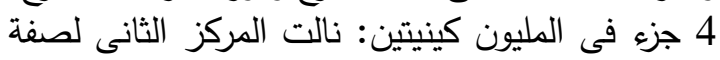

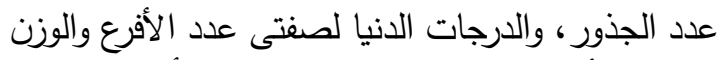

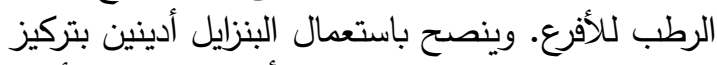

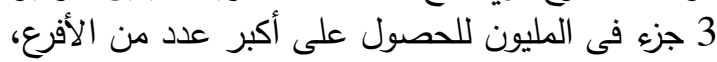

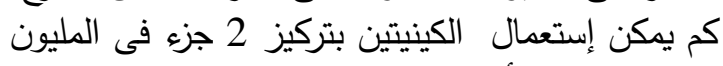

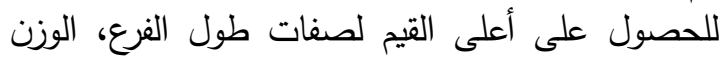
الرطب للأفرع، وعدد الجذور •

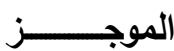

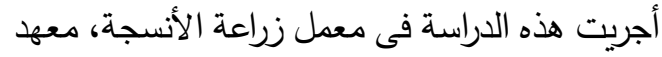

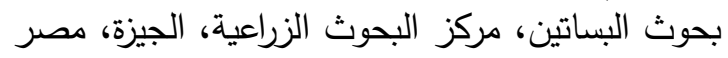

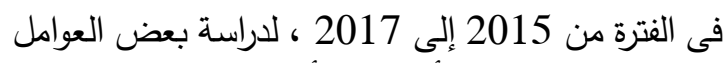

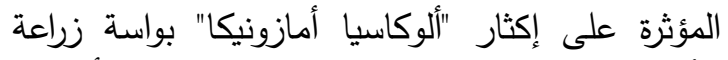

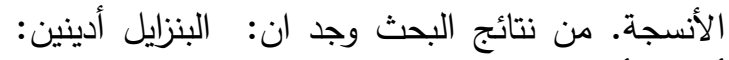

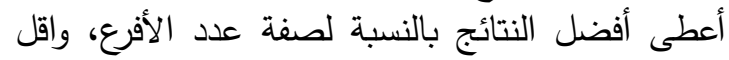

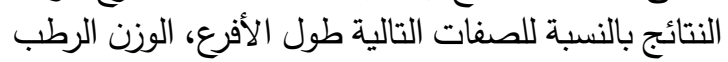

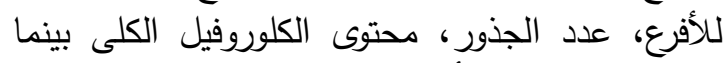

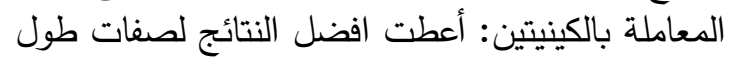

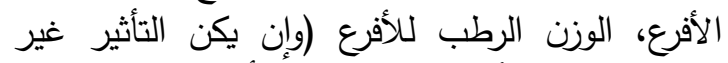

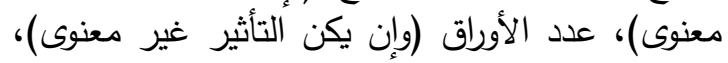
عدد الجذور ، محتوى الكلوروفيل الكلى.

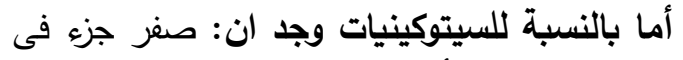

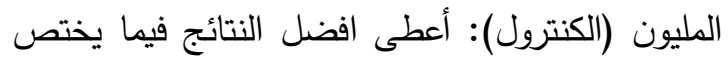
بصفات عدد الأوراق، عدد الجذور ومحتوى الكلون الكوروفيل

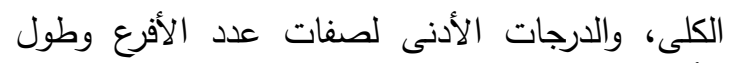

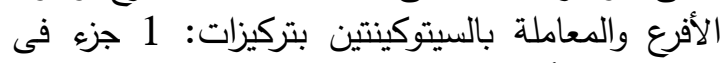

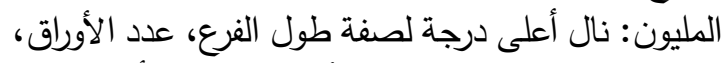

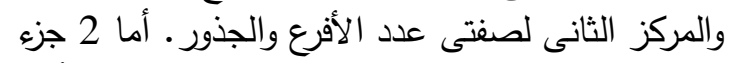

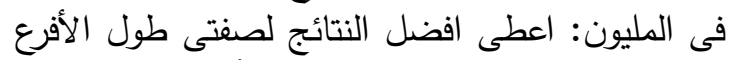

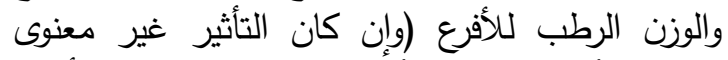
للصفة الأخيرة)، عدد الأوراق، ونال هذا لأنا التركيز أيضا

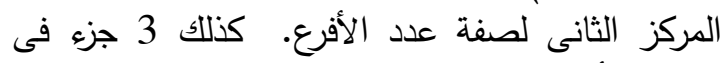
المليون: أحرز الدرجة العليا لصفة الأفة عدد الأفرع، والمركز الأدنى لصفة طول الأفرع، عدد الجذور ، الوزن الرطب الأب الركز 